\begin{tabular}{|c|c|}
\hline $\begin{array}{c}\text { Хорошо развиты творческие } \\
\text { способности }\end{array}$ & Привлекать молодёжь к участию в рекламных акциях \\
\hline Ценят эстетическую составляющую & Стремиться к оригинальным дизайнерским решениям \\
\hline $\begin{array}{c}\text { Чаще пользуются мобильным } \\
\text { телефоном, реже СМИ }\end{array}$ & $\begin{array}{c}\text { Активное использование смс-рассылки в рекламной кампании, } \\
\text { размещение в СМИ }\end{array}$ \\
\hline $\begin{array}{c}\text { Быстро оценивают, лучше } \\
\text { воспринимают 10-секундные } \\
\text { рекламные ролики }\end{array}$ & $\begin{array}{c}\text { Сократить продолжительность рекламных роликов } \\
\text { Ценят индивидуальные } \\
\text { особенности, противники } \\
\text { универсального }\end{array}$ \\
\hline
\end{tabular}

$$
* * *
$$

1. Что такое «бренд» и почему он важен для вашего бизнеса? [Электронный ресурс] // Артур Арутюнян. О брендах и маркетингах. - 2015. - Режим доступа: http://www.arturarutiunian.com/blog/2015/1/16/ guh2u0i7fceobfdx96n86jlaqai9n9 (дата обращения: 19.03.2018)

2. Рожина Е.Ю. К вопросу о брендбилдинге в России и за рубежом в контексте обучения профессиональному иностранному языку / Е.Ю. Рожина, И.В. Селиванова // Современные тенденции в образовании и науке: сборник научных трудов по материалам Международной научнопрактической конференции (Тамбов, 28.12.2014 г.): в 14 ч. - Ч. 10. - Тамбов: ООО «Консалтинговая компания Юком», 2014. - С. 94-99.

3. Кирдяшкина К.Е. Бренд-менеджмент: влияние на продвижение товара / К.Е. Кирдяшкина, О.Е. Чудинов // Фундаментальные и прикладные исследования в современном мире. - 2016. - № 13-2. C. $43-44$.

4. Атаджанов М. Переходное поколение в современном социуме: от поколения икс к Интернетпоколению / М. Атаджанов // Научный вестник Воронежского государственного архитектурностроительного университета. Серия: Социально-гуманитарные науки. - 2015. - № 4 (8). - С. $69-73$.

5. Рожина Е.Ю. Поколение Z как потребители товаров и услуг / Е.Ю. Рожина, И.В. Селиванова // Российское предпринимательство. - 2017. - Т. 18, № 24. - С.4289-4300.

\title{
Пржиленская И.Б., Шогенцукова Е.М. \\ Канонический кризис российской поэзии и прозы XXI века в контексте массовой культуры потребления
}

Московский педагогический государственный университет

(Россия, Москва)

doi: $10.18411 / s p c-26-03-2018-14$

idsp: 000001:spc-26-03-2018-14

На обывательском уровне идея кризиса современной российской литературы активно обсуждается. Кризис отмечается не столько в области прозы, сколько в области поэзии. Примечательно, что XXI век, век информационных технологий, предоставляет широкий простор для дискуссии на разных уровнях, чему способствует общедоступность сети Internet и широкий спектр виртуальных площадок. Свободно высказаться можно в любой плоскости, предполагающей комментарии, будь то сайт с профессиональной литературой или пустой слот комментария под аннотацией на сайте книжного магазина.

Предельно четко обозначил рамки поиска завязки современного литературного кризиса профессор кафедры русской литературы МГУ, М.М.Голубков в статье «Парадигмы современной литературы»: «Изменение культурного статуса литературы привело к потере важнейшей ее функции: формирования национального сознания, рефлексии о национальной судьбе <..> виновата не словесность, не художник, который больше не хочет быть «зрячим посохом», но объявляет себя беллетристом, виновато общество, распавшееся на первичные элементы и утратившее потребность (или способность?) к саморефлексии и самоидентификации - не только посредством литературы, но и других сфер общественного сознания» [Г].

Возможно, в основе трудностей неоднозначного восприятия россиянами современного искусства во всех его ипостасях лежит постсоветский кризис, 
общественная травма, на которую наложился отпечаток массового сознания. Именно массовый критический отклик, если можно использовать подобный термин в данном контексте, отличается безапелляционностью трактовок; эту оценочность можно развести в дихотомию «хорошо» - «плохо» без индифферентной переменной. Бессистемная организация современной литературы объясняется ее молодостью и построением новых канонов. Идеологическая картина советской пропаганды трансформировалась в революционный для восприятия период конца XX века и ожидаемо взяла курс на демократию. В таком случае неудивительно, что резкий перелом мировоззренческих настроений исказил каноническую картину в литературе. Жанровая взаимосвязь функционирует в общемировой сетке, когда как идея общественной действительности имеет точечный прицел на фокус-группу читателей. Борьба литераторов со вседозволенностью принесла свои плоды к началу нулевых, когда писательская самоорганизация преодолела период своего кризиса. Отсутствие цензуры и отказ от идейного зашоривания восприятия позволили надстраивать многослойные смыслы сначала в прозе, а затем и в поэзии. Т.Толстая, В.Пелевин, В.Сорокин, Д.Быков и многие другие выдающиеся фигуры мира прозы занялись смелыми экспериментами над словом и заложили фундамент для молодых писателей.

Начиная разговор об оценках искусства, мы не планируем прибегать к прибору «Поэтического метронома», беспристрастно оценивающего ритмы и рифму на основе закономерностей языковой стройности, но рассматриваем тему с точки зрения зрителя - общества, реципиента творчества.

О феномене массы и массового сознания начали научно говорить в последней четверти девятнадцатого века: Г.Лебон, Г.Тард, Э.Дюркгейм, Х.Ортега-и-Гассет, Э.Канетти, С.Московичи и другие научные деятели. Говорили по-разному, но сходились в очевидном: массовое сознание легко подвержено агитации и критично в своих оценках. Масса либо любит, либо ненавидит, и у массы свои культурные потребности. Характер этих потребностей можно раскрыть, опираясь на критерии массовой культуры: зрелищность, доступность для понимания (простота), стереотипность, способность воздействовать на бессознательное восприятие, тенденциозная, «хитовая» направленность; развлекательная, либо критическая злободневность.

Для литературы очень важен подход читателя, где читатель - априори критик. К беспристрастному чтению вне писательского контекста призывал Р.Барт в своем знаменитом постструктуралистическом эссе «Смерть автора», где говорится в частности и о том, как биографические контексты способны «наложить ограничения на текст». При всем удобстве для обоснованной критики, данный способ освоения литературного текста, по мнению Барта, является крайне неточным, так как автора и текст не следует рассматривать посредством наложения. Склонность искушенных читателей настраивать фокус на произведение через оптику биографии дает им читателям - власть над произведением, в первую очередь, в вариациях его осмысления, трактовке и рефлексии. Для современной литературы подобная свобода выбора у читателя, на наш взгляд, чревата искажением открытых посылов, так как жанровые рамки далеко не всегда определяют рамки контекстуальные. Двадцать первый век еще не дал литературе окрепнуть и позволить писателю самому формировать общественное мнение о произведении и тексте как таковом. Читатель нашего времени уверен, что свое мнение формирует самостоятельно, не под влиянием эпохи.

В этой связи уместно сказать, что для массового потребителя элитарная литература не имеет связи с читателем. К сожалению, она во многом не стыкуется с читателем даже для искушенного зрителя. Многослойность повествования и разность смыслов приводит к «преобладанию контекста над текстом<... отсюда прямая дорога к разрыву с читателем, которому неинтересен кулуарный быт, выплеснутый в тексты, и 
цитатные шарады, которые поэты загадывают друг другу, не заботясь о том, что эти тексты может прочесть также кто-то посторонний» [М.Генделев].

Кризис российской поэзии связан с популяризацией, так называемого велибра (неовелибра). Свободное стихосложение, значительно отличающееся от белого стиха, является любимой формой современных поэтов, становится «оплотом чувственности», невыразимым в канонических законах рифмования и в пределах цензурных границ. Состоятельность велибра как формы в двадцатом веке, очевидно, была связана с бесконечной любовью к экспериментам. К примеру, футуристы, провозгласив «манифест футуризма», призывали не только к слому любых поэтических канонов, но и к упразднению логической речи в принципе. Один из самых известных верлибров пера Алексея Крученых звучит следующим образом:

дыр булщыл

убешщур

скум

вы со бу

р л эз

Бессмысленное с первого взгляда сочетание гласных и согласных А.Крученых обозначил как начало «заумного языка», а дату написания (декабрь 1912 года) - датой создания новой речи. Ироничное, нарочито искаженное, построенное на отрицании настоящего и взгляде в будущее обращение к миру ярко прослеживается в творчестве и, само собой, выходит за пределы всех классических форм. «Заумному языку», например, было посвящено несколько серьезных работ, одна из которых - это монография американского литературоведа, русиста, Янечека Джеральда. Труд под названием «ZAUM: The Transrational Poetry of Russian Futurism» был издан в Сан Диего в 1996 году. К примеру, знаменитое четверостишье из «Алисы в Зазеркалье» - тоже стихотворение на «зауме», но зарубежного образца.

Однако же не только футуристы тяготели к верлибру, весь Серебряный век русской поэзии был увлечен экспериментами над каноном. У рядового читателя двадцать первого века, который не погружается в контекст, нет представления о том, что Серебряный век - век своеобразного белого стиха, а представление о том, что нынешняя поэзия не знает законов ритма и рифмы - есть. Соответственно, напрашивается вопрос: поэту действительно тесно в рифме или это тенденция?

«Верлибр стоит оценивать не только как литературное явление. Но и как явление социальное. Он позволяет самым широким массам почувствовать себя поэтами, общественно-значимыми личностями. Написание верлибров делает человека полноценным художником, в то время как написание плохих силлабо-тонических стихов плодит ряды графоманов» - отзывается о «новой поэзии» Евгений Степановлитератор, издатель, кандидат филологических наук, докторант РГГУ []. Спроецировав данное утверждение на проблему потребностей массового общества, поднятую в данной статье, хочется заметить, что в прерогативу массы входит не только потребление продуктов культуры, но и сотворчество. Интернет, как уже было сказано в начале, дает бесконечное пространство для публикации текстов. Интернет-страница есть у каждого начинающего или выдающегося поэта, музыканта, прозаика, художника, дизайнера, архитектора, инноватора, но, тем не менее, публикация произведений в открытых источниках не дает «статус» профессионала. Статья, опубликованная в интернет-дневнике, не прошедшая редактуру, регистрацию в заверенных источниках, процедуру издания, фактически и не имеет авторства в классическом понимании. Автор в интернете растворяется, становится анонимным. Хорошо это или плохо - сложно сказать.

В сложностях публикации кроется следующая проблема новой литературы. Создание образа профессионального поэта или прозаика - сложный механизм, 
состоящий не только из написания и издания, как, допустим, функция самиздата, но и непременно из продвижения автора специальными литературными агентами. Процедура эта дорогостоящая, множество талантливых и перспективных авторов не имеют финансовой возможности продвигаться официально. Гранты на издание книг, как и любые другие, имеют свой ряд условий, большой конкурс и специфический охват аудитории, поэтому интернет и стал основной площадкой, как для пишущих, так и для читающих. Такие поэты, как Кот Басе (Светлана Лаврентьева), Арчет (Андрей Кузнецов), Лемерт (Анна Долгарева), Вера Полозкова и другие получили известность благодаря сети Internet.

Для кого притягательна литература, построенная на руинах модернизма, неоднородная, злободневная, разножанровая? При всей «плоскости» потребностей массы, как заявлено в каноне, современную российскую литературу нельзя назвать плоской. Скорее, деление на жанры позволило каждому читателю найти книгу «по себе». Диссонанс между бумажными изданиями и интернет-публикациями, несомненно, существует. Авангардные тексты в основном публикуются в свободном доступе, тогда как в издательство поступает в большинстве своем то, на что имеется спрос. В данном случае отлаженно работает закон спроса, хотя уместно было бы предположить, что в вопросах творчества резонно выдвинуть авторов как инициаторов предложения, на который, исходя из предложенных положений, формируется спрос у читателей.

Свободный стиль повествования, неограненный жесткими рамками - остов литературы двадцать первого века. Текст требует еще большей свободы от всего: от формы, стиля, сюжета, рифм, иногда даже правил орфографии, пунктуации, синтаксиса; от контекста, ссылок, аргументации. Из пессимистичного тезиса о том, что новое столетие еще только в первой четверти, но постмодернизм как эпоха уже завершил свой виток, следует, что вскоре текст будет свободен и от читателя.

Постмодернизм, работающий на массы и с массами, опирается на стирание границ во имя воссоединения прошлого культуры с еe настоящим.. Образцы свободного стиха формируются с появлением подражателей, а канон структуры романа - с написанием типовых произведений. Как и любой вид искусства, литература так же находится в поисках, поэтому, безусловно, она существует и развивается. Неустойчивость потребностей толпы образует две резко конфликтующие точки зрения, и в этом разделении четко прослеживается возрастной признак: поколение, воспитанное на классике эпохи Просвещения и взрослевшее в эпохе модернизма, критикует современное искусство; поколение, воспитанное на классике модернизма и взрослеющее в эпохе постмодернизма, само является в процессе сотворчества, создавая время, в котором искусство происходит.

Порассуждав на тему кризиса литературы, хочется закончить словами М.М.Голубкова. В вышеупомянутой статье «Парадигмы современной литературы» он упоминает о дихотомии «горячих» и «холодных» культур К.Леви-Стросса, употребляя данные понятия в контексте современности: ««Горячая культура» полицентрична, каждый ее узел, вокруг которого группируются те или иные литературные явления, самоценен. В сущности, она не имеет центра и периферии. Современный литературный ландшафт ближе, скорее, к этому варианту. Разумеется, соблазн отнести нынешнюю культуру к «горячей» очень велик, но воздержимся пока...».

«Горячей» культура является тогда, когда ее потенциал востребован, когда общество нуждается в ее открытиях, когда искусство в целом и литература в частности оказывается значимым фактором общественного сознания, существенным обстоятельством национальной жизни. «Горячее» состояние не может быть следствием лишь процессов и явлений, имманентных литературе, но оказывается результатом национальной жизни в целом, ответом на общественные потребности. Нынешнее состояние литературы, когда общество не знает и не видит ее, вряд ли может 
соответствовать «горячей» стадии. Напротив, многообразие литературных красок не востребовано.

$$
* * *
$$

1. Барт Р. Избранные работы. Семиотика: Поэтика: Пер. с фр/ Р. Барт. М.: Прогресс, 1989.-203c.

2. Голубков М.М.Парадигмы Современной литературы/Русская и белорусская литературы на рубеже XX-ХХІ столетий.Часть 1.-Минск:РИВШ.2007.-с.3-11.

3. Московичи С. Век толп. Исторический трактат по психологии масс / С.Московичи. М.: 2011.-304c.

4. Степанов Е. Новый русский велибр: продолжение старых традиций // Дети Ра №2, 2010. (http://magazines.russ.ru/ra/2010/2/st28.html).

\section{Чуркина Н.А. \\ Ценности материнства в гендерной ментальности}

Сибирский государственныци университет телекоммуникаций и информатики (Россия, Новосибирск)

doi: $10.18411 / s p c-26-03-2018-15$

idsp: 000001:spc-26-03-2018-15

\section{Аннотация}

Ценность материнства традиционно относится к специфическим ценностям феминной ментальности. Женская ментальность, включающая ценности заботы, милосердия и добра, определяет особенности материнства как основы человеческого существования. Трансформация гендерной ментальности в современном обществе ведет к понижению значимости ценностей материнства и кризису семьи в целом.

Ключевые слова: материнство, архетипы, матриархат, ценности, гендерная ментальность.

В условиях кризиса семьи в современном обществе проблематика ценностей материнства представляется крайне актуальной. Исследование женских ценностей, составляющих содержание феминной ментальности, является актуальной темой социокультурного знания.

Зарождение этих ценностей обычно связывают с таким периодом человеческой истории как эпоха матриархата, в рамках которой значимость женского начала было особенно велика.

Архетип Матери, который с древности присутствует практически во всех человеческих культурах, воплощает базовые черты феминной ментальности. Материнство выражается в архетипических образах, связанных с символикой жизни, рождения и плодородия.

И.Я.Бахофен отмечал огромную значимость авторитета женщины в древности и утверждал, что «волшебство материнства» «выступает как действительно божественное начало любви, единения и мира» [7]. Высокая оценка ценностей «женского мира» способствовала утверждению в человеческом обществе заботы, милосердия и добра.

Утверждение подобных ценностей осуществлялось в рамках становления человеческого мышления на основе принципа дуальности. Уже с древности человек осмысливал окружающий мир посредством бинарных оппозиций - добро-зло, праволево, мужчина-женщина и пр.

Одной из важнейших бинарных оппозиций, которые пытался осмыслить человек уже в глубокой древности - это оппозиция «жизнь-смерть».

Смерть представлялась первобытным людям пугающим и необъяснимым явлением, которого невозможно избежать. Противоположностью смерти была жизнь, происхождение которой также трудно поддавалось какому-либо объяснению. Тем не 